Expenditures (prizes) $\ldots \ldots \ldots \ldots \ldots \ldots \ldots \ldots \ldots \ldots \ldots \ldots \ldots .200 .00$

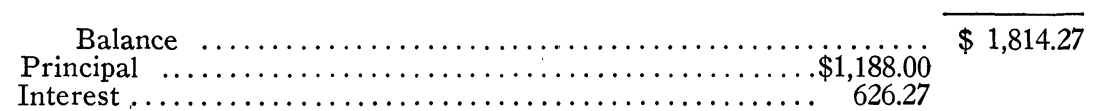

$\$ 1,814.27$

Cole Fund:

Balance from 1933:

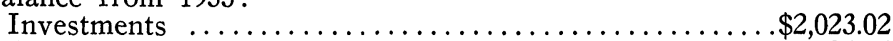

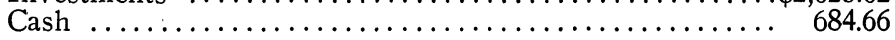

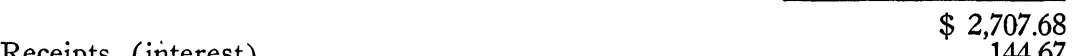

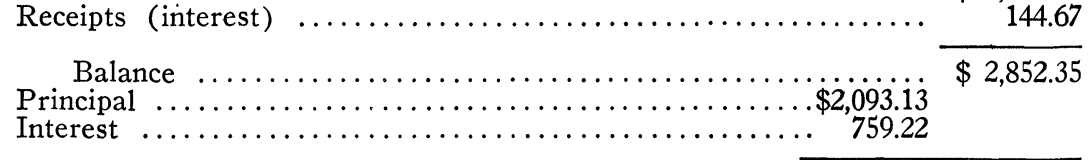

$\$ 2,852.35$

Moore Fund:

Balance from 1933:

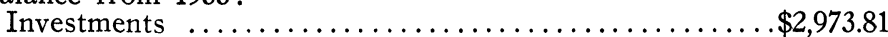

Cash $\ldots \ldots \ldots \ldots \ldots \ldots \ldots \ldots \ldots \ldots \ldots \ldots \ldots, 648.32$

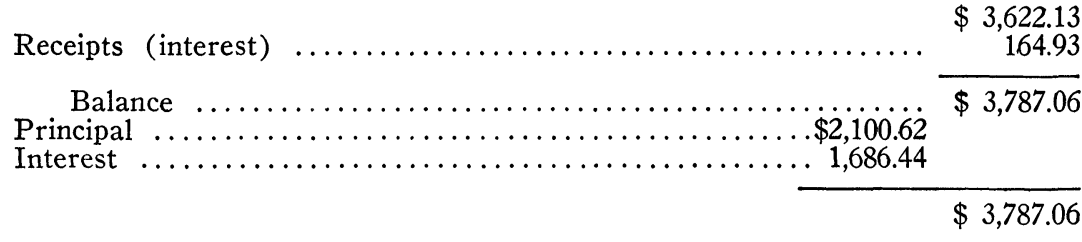

G. W. Mullins, Treasurer.

New YoRK, N.Y., December 1, 1934.

\title{
REPORT OF THE AUDITING COMMITTEE, 1934
}

We, the undersigned Auditing Committee, appointed by the American Mathematical Society, have this day audited the accounts of the Treasurer and in our opinion the following statement is correct:

\section{General Funds}

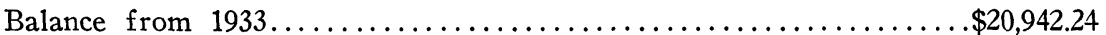

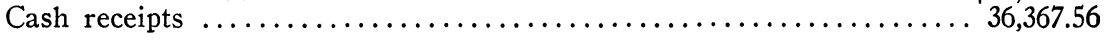

Disbursements ................................... $\begin{array}{r}\$ 57,309.80 \\ 34,131,94\end{array}$

Balance, December 1, 1934.........................\$23,177.86

Invested as follows:

Cash in Corn Exchange Bank, exclusive of outstanding checks..... \$ 3,331.61

Cash in Union Dime Savings Bank.......................... $3,616.14$

Cash in Bank for Savings............................... 2,556.23

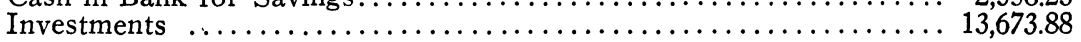




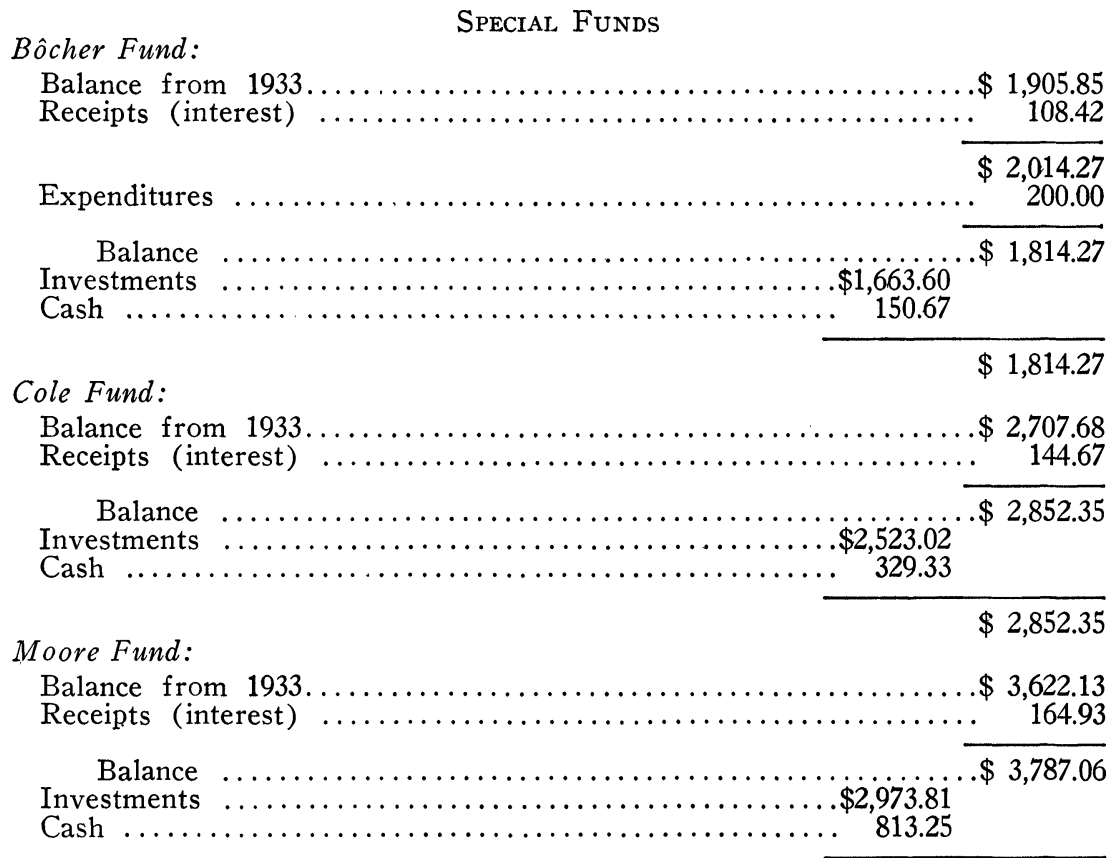
$\$ 6,247.62$.

The amount of reserve necessary to protect the life membership is now

$\begin{array}{ll} & \text { B. P. GiLL } \\ & \text { H. W. Redick } \\ \text { J. J. TANZOLA } & \text { Auditing Committee }\end{array}$

New YoRk, N.Y., December 12, 1934.

\footnotetext{
Receipts :

\section{REPORT OF THE TREASURER FOR THE YEAR 1935} BulletiN Fund

Balance from 1934 (including reprinting fund $\$ 1,576.05$ ) $\ldots \ldots \ldots \ldots \$ 2,920.02$

Appropriation from Dues for current volume.................. $\quad 8,400.00$

Sales, etc. :

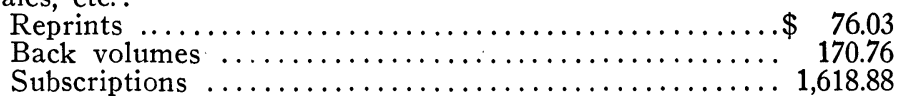

Expenditures :

Printing Bulletin (3 numbers for 1934, 9 numbers for

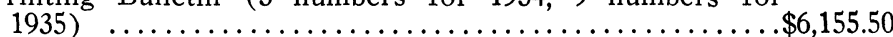

For Treasurer's expenses...................... 344.51

Clerk's annuity ............................... 130.05

Mailing, clerical, insurance, storage, etc............. 2,488.90

Clerical work on 10 -year index...................... 434.33

Balance (including reprinting fund, $\$ 1,312.48$ and reserve for List of Members, $\$ 400) \ldots \ldots \ldots \ldots \ldots \ldots$ 